\title{
PRESCHOOL TEACHERS' BELIEFS ABOUT THEIR OWN COMPETENCE IN WORKING WITH PRESCHOOL CHILDREN WHO SHOW EMOTIONAL AND BEHAVIOURAL DIFFICULTIES
}

\author{
ANJA VALENČIČ ŠTEMBERGAR ${ }^{1}$ AND JURKA LEPIČNIK VODOPIVEC ${ }^{2}$ \\ ${ }^{1}$ Zavod za gluhe in naglušne Ljubljana, Slovenija, ${ }^{2}$ Pedagoška fakulteta, Univerza na Primorskem, Koper, Slovenija, \\ Correspondence: Anja Valenčić Štembergar, valen.anja@gmail.com.
}

Received: 9.5.2016.

Original scientific paper

Accepted: 29.7.2016.

UDK: 376-056.34:371.12

\begin{abstract}
The central purpose of this paper is oriented toward determining the competence of preschool teachers in working with children who show emotional and behavioural difficulties. ${ }^{1}$ In the study, 82 teachers of preschool children participated. The data on the assessment of competence and the efficacy of preschool teachers in their work with children with whom BED are implied were acquired through a questionnaire that included modified versions of questionnaires on the self-assessment of competence (Teacher's Sense of Teacher Efficacy Scale, conducted by Tschannen-Moran \& Woolfolk Hoy, 2001) and their expectations about their own efficacy (Teacher Efficacy Scale, Gibson \& Dembo, 1984). We have found that preschool teachers rate their efficacy at the medium stage of agreement regarding the expectations of their own efficacy in working with children who show BED. We have also found that higher levels of education coupled with less working experience result in higher self-assessment of competence. Furthermore, the results of the study have shown that experience in working with children who show BED positively affects one's feeling of competence in working with these children. Besides this, the preschool teachers who rank their competence with children who show BED as higher also assess a higher level of competence in their efficacy of teaching children who show BED. In conclusion, we have also found that preschool teachers gain little knowledge during their initial education and training and more with independent work and additional training courses. The preschool teachers who rate the knowledge they have obtained through independent work also feel that their competence in working with children who show BED has grown as a result.
\end{abstract}

Key words: preschool child, emotional and behavioural difficulties, feeling of teachers' efficacy; teachers' competence

\section{INTRODUCTION}

Emotional and behavioural difficulties (BED) that appear in the preschool period are already among the most powerful predictors of more serious problems (delinquency, aggressiveness, abuse of substances, asocial behaviour) that the child could develop during their adolescence (McCabe \& Frede, 2007; Olson, et al., 1999; Rothbart \& Bates, 1998, in: Kochanska \& Knaack, 2003; Rothbart et al., 2004). Considering this, we can conclude that preschool, or more precisely, the preschool teacher, has an important function in preventing and intervening with these difficulties. This in turn brings us to the question about preschool teachers' competences for working with children who show BED. As Gebbie et al. (2012) say, the efficacy of applied approaches to working with children who point to BED depends on the qualification of the preschool teachers themselves. Part of this qualification, in turn, includes their belief in their own efficacy, that is, how they perceive their competence in positively influencing a child's behaviour (Gebbie et al., 2012).

Before defining the concept of competence and teachers' belief in their own efficacy, attention first needs to be drawn to the concept of the hidden cur-

1 Hereafter the abbreviation BED will be used to denote difficulties in the area of emotions and behaviour. 
riculum and preschool teachers' subjective theories. The hidden curriculum, whose starting point is the preschool teacher, is a set of intentions in preschool that are not specified by any of the formal documents, which could be understood as those deeds of the educator that are not planned activities (Kroflič, 2005), but which affect the child more than prescribed actions or any official curriculum (Batistič Zorec, 2004). An important characteristic of the hidden curriculum is its implicitness. An implicit theory (subjective theory) or "theory in practice" reflects the teachers' values in relation to how they see the child, what notions they have about childhood, and which theories of child development they advocate. An individual's implicit theories are manifested in their shaping of space, in their daily routine, and how they distribute roles and communicate with children (Pavičić Vukičević, 2013). These implicit theories also reflect personal ideology and ideas or stereotypes that are culturally conditioned and that constitute social expectations regarding the teacher's profession (preschool) (Kroflič, 2005).

The national document for working in public preschools in Slovenia, the Curriculum for Preschools, is not (as opposed to the Education Programme, which was in force before the present Curriculum) strictly structured - with the support of the principles of the curriculum's openness, in addition to the intended conduct it allows, it also takes into account the teacher's unintended conduct (Batistič Zorec, 2003), which means that, on the basis of their ideas, expectations, ideology, and the like, preschool teachers may arrange the living space of the playroom, select the toys they believe are appropriate for the children, link spontaneous and structured activities, etc. (Kroflič, 2005). The daily routine (as a component of the hidden curriculum) is then structured by the teachers' knowledge about the children's development and by their value-laden ideas about what is to the benefit of the child (Kroflič, 2005). Attention should be called here also to the implementation of the contemporary ideology of inclusion, which, concluding on the basis of the above statements, to a large extent depends on the individual educator, or more precisely, on their subjective theories. Several authors agree that preschool teachers lack knowledge about including children with special needs. They call attention to the set of "tacit knowledge" or the preschool teachers' subjective theories (attitudes, prejudices and stereotypes, expectations towards children, etc.), which relate to the success/failure of inclusion of children with special needs (Marentič Požarnik, 2003; Kay Manjack, 2013). Even a more detailed study of literature reveals that, according to preschool and primary school teachers, those children who show BED are exactly the group of children who are the most difficult to include in mainstream forms of education (OFSTED, 2004, in: Simon Ellis et al., 2008; Avramidis et al., 2000). This in turn is exactly what points to the importance of making preschool teachers aware of subjective theories, because teachers' attitudes towards children who show BED are related to their attitudes, values, and beliefs (Remšak, 2004). Furthermore, subjective theories have implications for educational, socialisation, and learning effects that are unplanned side products of the planned educational process, so it is important that these factors are reflected and given meaning within the profession (Jug, 2008).

The efficacy of individual teachers' work thus depends to a large extent on their subjective theories about childhood and education. The knowledge, beliefs, and attitudes of preschool teachers also affect their sensitivity to various kinds of children's needs (including the needs of children with BED), how they will respond to them, and whether they select an appropriate approach. As already mentioned, teachers' beliefs about their own competence and efficacy, or about how they positively affect a child's behaviour, is also an important part of the preschool teacher's subjective theories (Gebbie et al., 2012), so below we describe this concept in greater detail.

The concept of self-efficacy is derived from Bandura's social-cognitive theory. Bandura defines self-efficacy as "the belief in an individual's own ability to organise and execute certain knowledge needed for coping with a given situation." (Bandura, 1997, p. 2). The level of the individual's motivation, behaviour, and emotional states, however, are mostly shaped by subjective beliefs. Put differently, individuals will be motivated to cope with situations in which they personally feel competent and tend to avoid those which they believe to exceed their competence. Now, we can also tackle 
the concept of competence. The terms competence and self-efficacy are not synonymous. The concept of competence refers to professional knowledge and abilities (Gavora, 2010) and as such means preschool teachers' preparedness to perform their job (Bašić, 2008). Gustović-Ercegovac (1992, in: Bašić, 2003) says that the feeling of competence leads to satisfaction and power, while the feeling of incompetence arouses in preschool teachers feelings of apathy, helplessness, and anxiety. Selfefficacy, however, is what allows the successful use of competence. Self-efficacy is thus strongly regulated by each individual (Gavora, 2010) but also by the environment (i.e., the different experiences that the individual derives directly from the environment) (Bandura, 1997).

If the concept of self-efficacy is projected even further to the field of education, it can be defined as preschool teachers' belief about their efficiency in education and about their ability to affect children's learning results (Tschannen-Moran \& Woolfolk Hoy, 2001) or their belief in efficient and successful teaching (Gavora, 2010) that includes children with a lower degree of motivation and those who have lower abilities to learn (Tschannen-Moran \& Woolfolk Hoy, 2001).

Bandura (1977), too, calls attention to the feeling of self-efficacy, saying this relates to the preschool teacher's belief that difficulties can be overcome with an input of effort, while a lower level of efficacy on their part correlates to uncertainty about their own work (constantly inquiring about disciplining children and taking recourse to punitive methods of leading the group). Besides, a preschool teacher's lower assessment of their own efficacy relates to their belief that very little can be done with children who are not motivated to work and that, as teachers, they are limited by environmental factors which they cannot control. Preschool teachers with a high assessment of their own efficacy tend more toward creating a dynamic, learner-centred learning environment, in which they teach children how to assume responsibility (Bandura, 1977).

Another question that should be posed is that of how the feelings of competence and belief in one's own efficacy affect children's development. Indeed, preschool teachers' competence, including their knowledge, skills, and other personal characteristics derived from the aforementioned, are important for child's developmental progress, as well as for attaining the most important activities and achievements leading to positive mental development and the prevention of risky behaviour in preschool children (Bašić, 2008).

Preschool teachers' subjective theories (how they see the child and childhood, what expectations they have from children, what guides their actions, etc.) bring us rather quickly to the question of how competent preschool teachers feel in their work with children who manifest BED or how they understand their own efficacy and how this relates to the behaviour of such a child in the group. In this area, several studies have been carried out that in general confirm the relationship between self-efficacy and preschool teachers' successfulness in their work. Research results indicate that not all preschool teachers are equally motivated to try to manage children's behaviour, which is a direct factor of the teachers' belief about their own efficacy (Jordan \& Stanovich, 2003, in Gibbs \& Powell, 2012). The preschool teachers who believe more in their own efficacy or their own success with children are more motivated for leadership, they will invest more effort into preparing and performing an activity, and they will persist in their work for a longer time (Tschannen Moran \& Woolfolk Hoy, 2007). It has further been found that preschool teachers with a better feeling of self-efficacy use more positive intervention methods such as rewards or the improvement of behaviour, while preschool teachers with a lower feeling of self-efficacy use more authoritative and limiting methods of intervention when coping with difficult child behaviour (Brophy \& McCaslin, 1992). In one of the empirical studies where the correlation between individual belief about efficacy and responses to observed children's behaviour was examined, a positive correlation was found between teachers' views of their own efficacy and their responses to the actual behaviour of children. The preschool teachers who believed in their own efficacy more responded to authentic incidents, such as social rejection, shyness, lower performance, and aggressive behaviour, more appropriately (Almog \& Shechtman, 2007). It has further been found 
that teachers with a higher feeling of their own efficacy plan and organise their work at a higher level (Allinder, 1994, in: Tschhannen-Moran \& Woolfolk, Hoy, 2001), are more open to new ideas, and apply new learning and teaching methods that better suit the diverse needs of children (Berman et al., 1977, in: Tschhannen-Moran \& Woolfolk Hoy, 2001). Educational professionals' belief about their own efficacy, moreover, affects their persistence in solving the problems they come across in their work (Tschhannen-Moran \& Woolfolk Hoy, 2001), demonstrate less criticism towards children who make mistakes (Ashton \& Webb, 1986, in: Tschhannen-Moran \& Woolfolk Hoy, 2001), are more keen to learn, and are more committed to studying (Allinder, 1994, v Tschhannen-Moran \& Woolfolk Hoy, 2001). Preschool teachers with a high feeling of their own efficacy tend less to orient the children who indicate BED toward special education (Soodak \& Podell, 1993) and persist longer with children who have difficulties progressing (Gibson \& Dembo, 1984, in: Tschhannen-Moran \& Woolfolk Hoy, 2001).

In short, the teachers who believe in their own efficacy are more ready to assume responsibility for the learning of all children, including those with difficulties in development (Jerald, 2008), and are more tolerant towards inappropriate types of behaviour (Gibbs \& Powell, 2012).

\section{The purpose of the research and the research problem}

Considering the assertions listed above about the early treatment of children who show BED in the preschool period, the key role of the preschool teacher in preventing these problems and in intervention, and the fact that the efficacy of preschool teachers' work (in terms of quality and quantity) depends to a large extent on their subjective theories about childhood and education (self-assessment of competence and beliefs about efficacy), the central purpose of this study is oriented towards determining the competence of preschool teachers (to what degree they feel competent or what their expectations are regarding the efficacy of their work) in working with children who indicate BED. Based on this, it is possible to anticipate in which areas teachers believe themselves to be competent, and in which areas more emphasis should be placed on working toward changing teachers' subjective theories.

\section{Research goals}

The goal of this study is to examine the self-efficacy of preschool teachers in their work with children who show BED in terms of including them in the group, leading groups in which a child with BED has been included, and efficacy regarding learning in these children and in teaching them. In addition, the goal was also to examine preschool teachers' personal and overall effectiveness of teaching. Furthermore, our goal was to examine the relationship between teachers' feelings of self-efficacy and the level of education, work experience, acquired knowledge, and experience of those children showing signs of BED. We also reviewed teachers' estimates of their skills and the amount of knowledge they acquired during their training, with individual work, and with supplementary training.

\section{METHOD}

A descriptive and inferential method of empirical educational research was applied. A quantitative data gathering technique was applied to gather empirical data. This consisted of a survey questionnaire for preschool teachers.

\section{Participants}

Eighty-two teachers of preschool children participated in the study. Of these, 32 (39\%) had completed secondary education, 37 (45.1\%) were professional college graduates, and $13(15.9 \%)$ had a first-level university degree or more. The preschool teachers also varied in their work experience, 12 $(14.6 \%)$ had 5 or less years of work experience, 15 $(18.3 \%)$ had been at their current job for 5 to 10 years, $9(11 \%)$ for 10 to 15 years, and $46(56.1 \%)$ of them had more than 15 years of experience at work.

\section{Instruments}

A questionnaire for preschool teachers was used to gather empirical data. The first part of the ques- 
tionnaire consists of four closed-ended questions (education level; work experience; whether they have taught a child showing BED) and a five-point assessment scale for the teachers to assess their competence in working with children who show BED and the quantity of knowledge acquired in the course of schooling, independent work (reading literature, etc.), and supplementary training.

The second part of the questionnaire was an adapted version of the questionnaire on preschool teachers' feelings of efficacy (TSES - Teacher's Sense of Efficacy Scale - long version). This is a scale dedicated to measuring the feeling of preschool teacher's competence in educating children (Tschannen-Moran \& Woolfolk Hoy, 2001). For the needs of our study, the scale was adapted to examine the teachers' feeling of competence in educating children who show BED. The scale consists of 24 questions, against which the teachers assessed their competence or expressed how much they can do in a given case (e.g., How much can you do to motivate children who in your opinion show BED and who do not show interest in various activities?) This was expressed on a five-point scale 1 - nothing; 2 - little; 3 - medium; 4 - much; 5 very much (the original version Teacher's Sense of Efficacy Scale offered assessment on a 9-point scale, which we lowered to 5 to reduce the dispersion of responses). The Cronbach coefficient $\alpha$ was also computed $(\alpha=0.93)$, and the questionnaire was determined to be highly reliable.

With the support of the questionnaire, the preschool teachers assessed their competence in three areas of educating children who show BED (Tschannen-Moran \& Woolfolk Hoy, 2001): efficacy of including the children, efficacy in leading the group, and efficacy regarding childrens' learning and teaching them.

The third part of the questionnaire is an adapted version of the Teacher Efficacy Scale (TES; Gibson \& Dembo, 1984) - designed to measure preschool teachers' self-efficacy in their work with children (beliefs and relationships in connection with family environment and their own attitude toward working with children). For the purpose of the study, we adapted our scale, adding an item on children who show BED to the statements. The original version of the questionnaire consists of 30 claims; later, however, the number was reduced to 16 and then 9 claims, and thus its psychometric characteristics improved. Preschool teachers express their beliefs on a five-point scale, with the values representing: 1 - I do not agree at all; 2 - I do not agree; 3 - I cannot decide; 4 - I agree; 5 - I completely agree. The calculation of the Cronbach coefficient $\alpha(\alpha=0.72)$ shows that the questionnaire is moderately reliable. The structure of TES includes two dimensions:

- Personal teaching efficacy represents preschool teachers' belief that they possess the skills and abilities that allow them to facilitate children's learning (teachers' overall sense about their teaching efficacy) (Gibson \& Dembo, 1984; Gavora, 2010).

- General teaching efficacy represents preschool teachers' belief that it is possible to attain positive education and teaching effects in spite of external factors (family environment) (Gibson \& Dembo, 1984; Gavora, 2010).

\subsection{Collecting and processing the data}

The collected data were quantitatively processed using descriptive and inference statistics. The functions of the SPSS programme were applied for the statistical analysis. As the sample was small, for the statistical analysis we did not focus just on the statistical significance of the obtained parameters, but also carried out quantitative and effectual analyses. For determining the differences between the self-assessment of teachers' competence and teachers' belief about their own efficacy in working with children who show BED according to education level and experience at work, a one-way analysis of variance (ANOVA) was applied. The size of the effect was examined with the square of eta $\left(\boldsymbol{\eta}^{2}\right)$. The t-test of the differences between the arithmetic means for independent samples was applied to examine the differences between the self-assessment of preschool teachers' competence and preschool teachers' beliefs about their own efficacy in working with children who show BED according to their experience working with children who show BED. The size of the effect was measured with the Cohen's $d$ coefficient. The correlation between the self-assessment of com- 
petence and preschool teachers' beliefs about their own efficacy in work with children who show BED and the assessment of the knowledge obtained in the course of initial study, with independent work, and with supplementary education was tested with Pearson's correlation coefficient (r).

\section{RESULTS}

Descriptive statistics of the self-assessment of preschool teachers' competence in relation to some areas of knowledge and skills in working with children who show BED and preschool teachers' beliefs about their own efficacy in working with children who show BED

Table 1. Descriptive statistics of preschool teachers' self-assessment of their efficacy in including children who show BED in a group, leading groups in which a child showing BED is included, and children's learning and teaching them

\begin{tabular}{|l|c|c|}
\hline Area od efficacy & M & SD \\
\hline Including children in the group & 3.34 & 0.62 \\
\hline Leading the group & 3.43 & 0.54 \\
\hline Learning and teaching & 3.47 & 0.60 \\
\hline
\end{tabular}

Notes: $\mathrm{M}=$ arithmetic mean; $\mathrm{SD}=$ standard deviation

We have examined (see Table 1) how much in a given case preschool teachers can do in their work with children who show BED and found that preschool teachers define their efficacy in all three of these areas (including children with BED in the group [M=3.43]; leading the group [ $\mathrm{M}=3.43]$; and efficacy in learning and teaching $[\mathrm{M}=3.47]$ ) as medium. Testing the degree of preschool teachers' agreement regarding personal and overall efficacy of teaching children who show BED (see Table 2 ), it turned out that preschool teachers in general agree $(M=3.75)$ with the claims referring to the personal efficacy of teaching. They agree slightly less $(M=3.38)$ with the claims referring to overall efficacy of teaching.

Table 2. Descriptive statistics of agreement with claims referring to preschool teachers' beliefs about personal and overall efficacy of children who show $B E D$.

\begin{tabular}{|l|c|c|}
\hline Area of efficacy & M & SD \\
\hline Personal efficacy & $\mathbf{3 . 7 5}$ & 0.51 \\
\hline Overall efficacy & $\mathbf{3 . 3 8}$ & 0.68 \\
\hline
\end{tabular}

Notes: $\mathrm{M}=$ arithmetic mean; $\mathrm{SD}=$ standard deviation

Furthermore, we also examined whether there are differences in preschool teachers' self-assessment of their own efficacy according to the level of education.

\section{Differences in the self-assessment of preschool teachers' competence in relation to certain knowledge and skills in working with children who show BED and teachers' beliefs about their own efficacy in working with children who show BED, according to level of education.}

The result of a one-way analysis of variance (see Table 3) did not show any statistically significant differences in the self-assessment and beliefs of preschool teachers about the efficacy of teaching children who show BED according to the level of

Table 3. Results of a one-way analysis of differences in teachers'self-assessment of efficacy and the personal and general efficacy of teaching children who show BED, according to level of education.

\begin{tabular}{|c|c|c|c|c|c|c|}
\hline & \multirow[t]{2}{*}{ Area of efficacy } & \multicolumn{3}{|c|}{ Education level } & \multirow[t]{2}{*}{$\mathrm{F}^{*}$} & \multirow[t]{2}{*}{$\eta 2$} \\
\hline & & $\begin{array}{l}S(\mathbf{N}=32) \\
M(\text { SD) }\end{array}$ & $\begin{array}{c}\mathbf{P}(\mathbf{N}=37) \\
M(\mathbf{S D})\end{array}$ & $\begin{array}{c}\mathrm{U}(\mathrm{N}=13) \\
\mathrm{M}(\mathrm{SD})\end{array}$ & & \\
\hline \multirow{3}{*}{$\begin{array}{l}\text { Self-assessment } \\
\text { of competence }\end{array}$} & Including children & $3.31(0.59)$ & $3.45(0.61)$ & $3.65(0.73)$ & 1.48 & 0.04 \\
\hline & Leading the group & $3.35(0.57)$ & $3.5(0.51)$ & $3.44(0.51)$ & 0.63 & 0.02 \\
\hline & Learning and teaching & $3.3(0.66)$ & $3.52(0.52)$ & $3.74(0.56)$ & 2.84 & 0.07 \\
\hline \multirow{2}{*}{$\begin{array}{l}\text { Belief about } \\
\text { efficacy }\end{array}$} & PET & $3.76(0.37)$ & $3.78(0.63)$ & $3.67(0.47)$ & 0.02 & 0.01 \\
\hline & GET & $3.44(0.69)$ & $3.41(0.66)$ & $3.14(0.66)$ & 0.99 & 0.02 \\
\hline
\end{tabular}

Notes: $\mathrm{S}=$ secondary education; $\mathrm{P}=$ professional higher education; $\mathrm{U}=$ university - first level or more; $\mathrm{PET}=\mathrm{Personal}$ efficacy of teaching; GET=general efficacy of teaching; $F=$ results of one-way analysis of variance (ANOVA); $\eta 2=$ the value of eta squared. *If the assumption of homogeneity of variance was not justified, the Welch test (approximation test) was applied. * $p$ $<.05 ; * * \mathrm{p}<.01 ; * * * \mathrm{p}<.001$ 
education attained. In spite of the statistical insignificance of the result, the eta squared $\left(\boldsymbol{\eta}^{2}\right)$ shows a moderate effect in the area of self-assessment of the competence of learning and teaching. We can read from Table 3 that preschool teachers with a professional higher education degree $(\mathrm{M}=3.52)$ and those with a university degree $(M=3.74)$ estimate that they can do more in the area of learning in children with BED and in teaching them, than preschool teachers with secondary technical education $(\mathrm{M}=3.30)$. Furthermore, we were interested whether there are differences in the self-assessment of competence and beliefs of preschool teachers regarding personal and general efficacy in teaching children who show BED according to work experience (see Table 4).

\section{Differences in preschool teachers' self- assessment of competence in relation to certain knowledge and skills in their work with children who show BED and preschool teachers' beliefs about their efficacy in their work with children who show BED according to work experience.}

A one-way analysis of variance (see Table 4) did not yield any statistically significant difference in the self-assessment of competence and beliefs of preschool teachers about the efficacy of teaching children who show BED in relation to work experience. A low to moderate value of eta squared $(\eta 2)$ in the area of leading the group indicates that, in comparison to other preschool teachers (who estimate their efficacy as moderate), preschool teachers with 5 or less years of experience say they can do a lot
$(M=3.64)$. From Table 4 we can further read a moderate effect of eta squared $(\eta 2=0,05)$ among preschool teachers with less work experience (up to 10 years), who more strongly agree $(\mathrm{M}=3.53 ; \mathrm{M}=3.49)$ that it is possible to achieve effects of teaching children who show BED in spite of external factors.

We also examined (see Table 5) any differences in preschool teachers' self-assessment of competence and their beliefs about their own efficacy in teaching children who show BED in relation to whether they have had experience in working with children who show BED.

\section{Differences in preschool teachers' self- assessment of their competence in relation to certain knowledge and skills in working with children who show BED and preschool teachers' beliefs about their own efficacy in working with children who show BED}

The result of the t-test showed no statistically significant differences in the self-assessment of competence and in the belief of preschool teachers about their own efficacy in working with children who show BED. The value of Cohen's $d$ coefficient nevertheless indicates a moderate effect in efficacy in including children, as preschool teachers who have experience in working with children who show BED believe that they can do more $(\mathrm{M}=3.46)$ than the preschool teachers with no such experience believe they can (M=3.09). Cohen's $d$ coefficient also indicated a moderate effect in the area

Table 4. Results of a one-way analysis of the variance in the differences in the self-assessment of competence and preschool teachers'beliefs about their own efficacy in their work with children who show BED, according to work experience

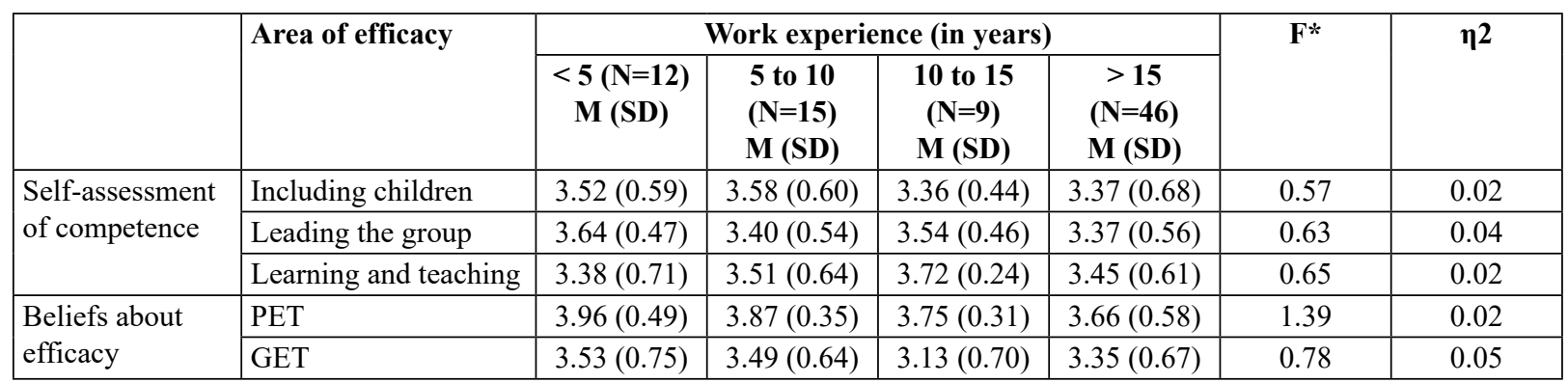

Notes:. PET=Personal efficacy of teaching; GET=general efficacy of teaching; $F=$ results of one-way analysis of variance (ANOVA); $\eta 2$ =the value of eta squared; *If the assumption of homogeneity of variance was not justified, the Welch test (approximation test) was applied. * $\mathrm{p}<.05 ; * * \mathrm{p}<.01 ; * * * \mathrm{p}<.001$. 
Table 5. Results of t-test of differences between the arithmetic means in the self-assessment of competence and preschool teachers' beliefs about their own efficacy in the work with children who show BED, according to experience working with children who show BED

\begin{tabular}{|c|c|c|c|c|c|}
\hline & \multirow[t]{2}{*}{ Area of efficacy } & \multicolumn{2}{|c|}{ Experience } & \multirow{2}{*}{$\frac{t \text {-test* }}{t}$} & \multirow[t]{2}{*}{ d } \\
\hline & & Yes $(\mathrm{N}=75) \mathrm{M}(\mathrm{SD})$ & No $(N=7) M(S D)$ & & \\
\hline \multirow{3}{*}{$\begin{array}{l}\text { Self-assessment } \\
\text { of competence }\end{array}$} & Including children & $3.46(0.62)$ & $3.09(0.62)$ & 1.52 & 0.6 \\
\hline & Leading the group & $3.43(0.55)$ & $3.42(0.44)$ & 0.11 & 0.02 \\
\hline & Learning and teaching & $3.48(0.61)$ & $3.41(0.40)$ & 0.29 & 0.12 \\
\hline \multirow{2}{*}{$\begin{array}{l}\text { Beliefs about } \\
\text { efficacy }\end{array}$} & PET & $3.75(0.49)$ & $3.82(0.73$ & -0.37 & -0.11 \\
\hline & GET & $3,36(0,69)$ & $3,57(0,48)$ & -0.79 & -0.35 \\
\hline
\end{tabular}

Notes: PET=Personal efficacy of teaching; GET=general efficacy of teaching; d=value of Cohen's coefficient. *If the assumption of homogeneity of variance was not justified, the approximation t-value was used. $* \mathrm{p}<.05 ; * * \mathrm{p}<.01 ; * * * \mathrm{p}<.001$.

of general efficacy of teaching $(\mathrm{d}=-0.35)$; it can namely be read in comparison to those preschool teachers with experience in the work with children who show BED $(M=3.36)$, the preschool teachers who have no such experience agree more strongly $(\mathrm{M}=3.57)$ that the effects of teaching children who show BED are obtainable in spite of external factors. It can further be read from the table that a majority of the preschool teachers have had experience with children who, in their belief, show BED.

Furthermore, the relation between preschool teachers' assessment of competence with the self-assessment of competence and preschool teachers' belief about their own efficacy in their work with children who show BED (see Table 6) was examined.

\section{The relation between preschool teachers' self-assessment of competence concerning certain knowledge and skills in their work with children who show BED, and preschool teachers' beliefs about their own efficacy in their work with children who show BED and the qualitative assessment of the work with children who show BED}

In spite of the statistical insignificance of the relationship, the value of Pearson's correlation coefficient indicates in the area of self-assessment of competence for learning and teaching that there is a moderate and positive $(\mathrm{r}=0.38)$ correlation, which means with a preschool teacher's higher rating of the qualifcation, also the rating of the efficacy of learning and teaching increases.

We were also interested in identifying any relations between the self-assessment of competence and preschool teachers' beliefs about their own effi-
Table 6. Result of Pearson's correlation coefficient of the relationship between the assessment of the degree of qualification and the self-assessment of competence and preschool teachers' beliefs about their own efficacy in their work with children who show BED

\begin{tabular}{|l|l|c|c|}
\hline \multirow{2}{*}{} & Area of efficacy & \multicolumn{2}{|c|}{$\begin{array}{c}\text { The degree of } \\
\text { qualification } \\
\mathbf{( M = 2 . 8 2 ;} \\
\text { SD=0.88) }\end{array}$} \\
\cline { 3 - 4 } & & $\mathbf{r}$ & $\mathbf{P}$ \\
\hline \multirow{2}{*}{$\begin{array}{l}\text { Self- } \\
\text { assessment of } \\
\text { competence }\end{array}$} & Including children & -0.02 & 0.85 \\
\cline { 3 - 4 } & Leading of the group & -0.05 & 0.66 \\
\cline { 2 - 4 } $\begin{array}{l}\text { Beliefs about } \\
\text { efficacy }\end{array}$ & Learning and teaching & 0.38 & 0.74 \\
\cline { 2 - 4 } & PET & -0.04 & 0.72 \\
\hline
\end{tabular}

Notes. $\mathrm{M}=$ arithmetic mean; $\mathrm{SD}=$ Standard deviation; PET=Personal efficacy of teaching; GET=general efficacy of teaching;

cacy in their work with children who show BED and the assessment of the knowledge obtained in the course of the initial study, with independent work and with supplementary education (see Table 7).

The relationship between preschool teachers' self-assessment of competence concerning certain knowledge and skills in their work with children who show BED and preschool teachers' beliefs about their own efficacy in their work with children who show BED, and the assessment of the knowledge attained in the course of initial studies, with the support of literature and with supplementary education

Pearson's correlation factor has shown a statistically significant positive correlation in assessing 
Table 7. Result of Pearson's correlation coefficient of the relation between preschool teachers'self-assessment of competence and preschool teachers' belief about their own efficacy in working with children who show BED and the assessment of knowledge acquired in the course of initial studies, with the support of literature, and with supplementary education

\begin{tabular}{|c|c|c|c|c|c|c|c|}
\hline & & \multicolumn{6}{|c|}{ Assessment of obtained knowledge } \\
\hline & & \multicolumn{2}{|c|}{$\begin{array}{l}\text { In the course of initial } \\
\text { study }(M=1.93 ; S D=0.81)\end{array}$} & \multicolumn{2}{|c|}{$\begin{array}{l}\text { Independent work } \\
(\mathrm{M}=3.22 ; \mathrm{SD}=0.90)\end{array}$} & \multicolumn{2}{|c|}{$\begin{array}{c}\text { Supplementary } \\
\text { education }(M=3.27 \\
\mathrm{SD}=\mathbf{3 . 5 0})\end{array}$} \\
\hline & & $\mathbf{r}$ & $\mathbf{P}$ & $\mathbf{r}$ & $\mathbf{P}$ & $\mathbf{r}$ & $\mathbf{P}$ \\
\hline \multirow{3}{*}{$\begin{array}{l}\text { Self-assessment } \\
\text { of competence }\end{array}$} & Including children & 0.17 & 0.13 & $0.30 * *$ & 0.01 & 0.13 & 0.25 \\
\hline & Leading the group & 0 & 0.99 & 0.09 & 0.43 & 0.02 & 0.88 \\
\hline & Learning and teaching & -0.02 & 0.88 & $0.25^{*}$ & 0.02 & 0.2 & 0.08 \\
\hline \multirow{2}{*}{$\begin{array}{l}\text { Beliefs about } \\
\text { efficacy }\end{array}$} & PET & 0.15 & 0.89 & -0.03 & 0.8 & 0.03 & 0.81 \\
\hline & GET & 0.14 & 0.21 & -0.06 & 0.61 & 0.05 & 0.65 \\
\hline
\end{tabular}

Notes. $\mathrm{M}=$ =arithmetic mean; $\mathrm{SD}=$ Standard deviation; $\mathrm{PET}=$ Personal efficacy of teaching; GET=general efficacy of teaching;

efficacy in including children in the group $(\mathrm{P}=0.01)$ and the self-assessment of efficacy in the area of learning and teaching $(\mathrm{P}=0.002)$ with the assessment of the knowledge acquired through independent work. Higher self-assessment of strength in including children and in teaching them proved to be connected with a higher assessment of the knowledge obtained with the support of supplementary education. From the table we can further read that preschool teachers have obtained the most knowledge with the support of supplementary education $(\mathrm{M}=3.27)$ and with independent work $(\mathrm{M}=3.22)$, and the least in the course of their initial studies $(\mathrm{M}=1.93)$.

\section{DISCUSSION}

We have found preschool teachers assess as medium their competence in including children who show BED, leading a group of children that includes a child who shows BED, as well as their competence regarding learning in these children and teaching them. This can mean preschool teachers are insufficiently equipped with knowledge and skills needed for working with children who show BED. In addition, preschool teachers agree with the assertions about personal efficacy, and slightly less with the assertions in the field of general efficacy of teaching children who show BED. This too points to an exceedingly low degree of agreement, which can mean that preschool teachers do not believe enough in their own skills and abilities that facilitate children's learning, and that they believe less in the assertion that the effects of learning and teaching can be attained in spite of external factors (family environment). These findings can be linked to the conclusions of the study that preschool teachers are not sufficiently equipped with knowledge about children who show BED, who for preschool teachers are the most difficult group to include in mainstream forms of education (OFSTED, 2004, in: Simon Ellis et al., 2008; Avramidis et al., 2000).

We have further concluded that a higher level of education attained affects a higher self-assessment of competence and efficacy in learning and teaching. Besides this, also preschool teachers with less work experience rate their self-assessed competence higher than preschool teachers with more work experience and agree more that effects in learning and teaching can be attained in spite of external factors. We can conclude that preschool teachers with a higher level of education are better equipped with knowledge in the area of learning in children who show BED and in teaching them. This finding can be linked to the assertions of Peček Čuk (1997) and Schmidt (2001), who say that, for improved qualifications of preschool teachers, changes should already be made in undergraduate studies, as students do not acquire a sufficient amount of knowledge for working with children with special needs.

We have found, moreover, that preschool teachers who have experience working with children rate their competence in the area of children who show BED higher than preschool teachers who have no such experience. This can be explained by the fact that an assessment of preschool teachers' 
self-efficacy that allows for the successful use of competences (Gavora, 2010) depends on the prior experience that the individual acquires immediately from the environment (Bandura, 1997). The following conclusion is also surprising, namely that preschool teachers who have had experience working with children who show BED agree less with the assertions in the field of general efficacy of teaching, or that it is possible to attain the effects of learning and teaching in spite of external factors (family environment). This finding can lead us to thinking that the family environment of a child who shows BED can make the work of preschool teachers more complicated and thus hinder the success of the child's progress. We were also interested in finding out how preschool teachers assess their qualification for their work with children who show BED. On a five-point scale, they rated their qualification as medium. We have further found that preschool teachers who rate their qualification in working with children who show BED also rate higher their competence in the area of efficiency of learning and teaching children who show BED. Finally, we also examined the estimate of the amount of knowledge attained and found preschool teachers had assessed they had attained the least knowledge (none or little) in the course of their initial schooling/study; they assessed as medium the knowledge they had gained through independent work (reading literature) and with supplementary education. Marentič Požarnik (2003) also calls attention to this problem, saying more content from the field of special pedagogies should be built into the system of preschool-teacher education. We have further found that preschool teachers who rate higher their attained knowledge about working with children who show BED also better assess their efficacy in including children who show BED, as well as their efficacy in the area of learning and teaching. This means that preschool teachers who attain knowledge through independent work also feel more competent about their work with children who show BED.

\section{CONCLUSIONS}

The obtained results must be interpreted considering that not a large sample of preschool teachers was included. Beside this, the data were gathered with the support of instruments that have not been standardised for Slovenia. The results of the self-assessment of competence and preschool teachers' beliefs about their efficacy in working with children who show BED nevertheless confirm that it is necessary to invest in preschool teachers' competences in such a way that they develop toward supporting the mental development of children who show BED. In this way, the effects of these difficulties in the later lives of the children would be prevented or at least mitigated, as difficulties with behaviour and emotions of children in the preschool period are among the most powerful predictors of the child's more serious problems in the period of adolescence (delinquency, aggressiveness, abuse of substances, asocial behaviour) (McCabe \& Frede, 2007; Olson, et al., 1999; Rothbart \& Bates, 1998, in: Kochanska \& Knaack, 2003; Rothbart et al., 2004). This exactly, however, points to the importance of awareness-raising about the subjective theories of preschool teachers, as relationships towards children who show BED are influenced by the attitudes, values, and beliefs of preschool teachers (Remšak, 2004). Besides, the consequences of subjective theories have unplanned effects on education, socialisation, and learning, which are manifested as peripheral products of planned educational and learning processes; it is important that these factors are reflected upon and that they are given significance within the profession (Jug, 2008). This points to the need to change preschool teachers' subjective theories with the support of reflection upon their own work. In addition, more content related to children with special needs, including children who show BED, should be integrated directly into the preschool teachers' syllabi. That is, several authors agree that preschool teachers lack knowledge in the area of including children with special needs. In addition, they point to the influence of subjective theories or preschool teachers" "tacit knowledge" about the effectiveness/ineffectiveness of implementing the inclusion of children with special needs into mainstream education forms (Marentič Požarnik, 2003; Kay Manjack, 2013). 


\section{REFERENCES}

Almog, O., Schechtman, Z. (2007): Teachers' democratic and efficacy beliefs and styles of coping with behavioural problems of pupils with special needs. European Journal of Special Needs Education, 22, 2, 115-129.

Avramidis, E., Bayliss, P., Burden, R. (2000): Student teachers attitudes towards the inclusion of children with special educational needs in the ordinary school. Teaching and Teacher Education, 16 , 277-293.

Bandura, A. (1977): Self-efficacy: Toward a unifying theory of behavioral change. Psychological Review, 84, 2 , $191-215$.

Bašić, J. (2008): Kompetentnost odgajatelja i prevencija rizičnih ponašanja djece u predšolskim ustanovama. Zagreb: Edukacijsko-rehabilitacijski fakultet Sveučilišta u Zagrebu.

Batistič Zorec, M. (2004): Subjektivne teorije vzgojiteljic in kurikularna prenova vrtcev. Sodobna pedagogika, 55, 2, 128-139.

Brophy, J., McCaslin, M. (1992): Teachers' Reports of How They Perceive and Cope with Problem Students. The Elementary School Journal, 93, 1, 3-68.

Gavora, P. (2010): Slovak pre-service teacher self-efficacy: theoretical and research considerations. The New Educational Review, 21, 2, 17-30.

Gebbie, D. H., Ceglowski, D., Taylor , L. K., Miels, J. (2012): The role of Teacher Efficacy in Strengthening Classroom Support for Preschool Children with Disabilities Who Exhibit Challenging Behaviors. Early Childhood Education, 40, 35- 46.

Gibbs, S., Powell, B. (2012): Teacher efficacy and pupil behaviour: The structure of teachers' individual and collective beliefs and their relationship with number od pupils excluded from school. British Journal of Educational Psychology, 82, 564-584.

Jerald, C. D. (2007): Believing and Achieving. The Center for Comprehensive School Reform and Improvement. Posjećeno 1. 1. 2016. Na mrežnoj stranici: http://www.centerforcsri.org/files/CenterIssueBriefJan07.pdf.

Jug, A. (2008): Subjektivne teorije kot kazalnik kakovosti vzgojno-izobraževalnega dela. Sodobna pedagogika, 2, $44-59$.

Kay Manjack, S. (2013): Relations Between Secondary Art Teachers' Personal Education Theories And Attitudes About Inclusion. Chicago: University of IIinois.

Kochanska, G., Knaack, A. (2003): Effortful control as a personality characteristic of young children: Antecedents, correlates, and consequences. Journal of Personality, 71, 6, 1087-1112.

Kroflič, R. (2005): Vzgojiteljica - izhodišče prikritega kurikuluma v vrtcu. U: Vrbovšek, B., (ur.): Prikriti kurikulum v kurikulu - rutina ali izziv v vrtcu (str. 10-16). Ljubljana: Supra.

Marentič - Požarnik, M. (2003): Temelj uspešnega vključevanja učencev s posebnimi potrebami so ustrezno usposobljeni učitelji. Sodobna pedagogika, Posebna izdaja, 104-113.

Olson, S. L., Schilling, E. M., Bates, J. E. (1999): Measurement of impulsivity: Construct coherence, longitudinal stability, and relationship with externalizing problems in middle childhood and adolescence. Journal of Abnormal Child Psychology, 27, 151-165.

Pavičić Vukićević, J. (2013): Uloga implicitne teorije nastavnika u skrivenom kurikulumu suvreme škole. Pedagogijska istraživanja, 10, 1, 119-133.

Peček Čuk, M. (1997): Učitelji in integracija učencev s posebnimi potrebami. U: Destovnik, K., Matovič, I. (ur.): Izobraževanje učiteljev ob vstopu v tretje tisočletje: stanje, potrebe, rešitve: zbornik prispevkov (str. 320 — 327). Ljubljana: Pedagoška fakulteta.

Remšak, J. (2004): Disciplinske strategije kot del implicitnih teorij učiteljev. Sodobna pedagogika, 55, 2, 108 -126. 
Rothbart, M.K., Ellis, L. K., Rosario Rueda, M., Posner, M. I. (2004): Developing Mechanisms of Temperamental Effortful Control. Journal of Personality, 71, 6, 1113-1144.

Schmidt, M. (2001): Socialna integracija otrok s posebnimi potrebami v osnovno šolo, Maribor: Pedagoška fakulteta.

Soodak, L., Podell, D. (1993): Teacher efficacy and student problem as factors in special education referral. Journal of Special Education, 27, 66-81.

Tschannen-Moran, M., Woolfolk Hoy, A. (2001): Teacher efficacy: capturing an elusive construct. Teaching and Teacher Education, 17, 783-805.

Tschannen-Moran, M., Woolfolk Hoy, A. (2007): The differential antecedents of self-efficacy beliefs of novice and experienced teachers. Teaching and Teacher Education, 23, 944-956.

\section{VJEROVANJA ODGOJITELJA O VLASTITIM KOMPETENCIJAMA ZA RAD S PREDŠKOLSKOM DJECOM KOJA POKAZUJU EMOCIONALNE TEŠKOĆE I PROBLEME U PONAS̆ANJU}

Sažetak: Cilj ovog rada bila je analiza samoprocijenjenih kompetencija odgojitelja za rads djecom koja pokazuju emocionalne teškoće i probleme u ponašanju. U istraživanju su sudjelovala 82 odgojitelja predškolske djece. Podaci o samoprocjenjenoj kompetentnosti i samoefikasnosti odgojitelja u radu s djecom koja pokazuju emocionalne teškoće i probleme u ponašanju prikupljeni su putem upitnika koji je uključivao modificirane verzije upitnika Teacher's Sense of Efficacy Scale (Tschannen-Moran $i$ Woolfolk Hoy, 2001) $i$ Teacher Efficacy Scale (Gibson i Dembo, 1984). Rezultati istraživanja pokazuju da odgojitelji svoju samoefikasnost u radu s djecom koja imaju emocionalne teškoće i probleme u ponašanju procjenjuju osrednjom te da su viša razina obrazovanja i kraće radno iskustvo povezani s višom samoprocjenom kompetentnosti. Rezultati istraživanja pokazuju također da su iskustva u radu s ovom djecom pozitivno povezana s većim osjećajem kompetentnosti u odgojitelja. Nadalje, odgojitelji koji bolje procjenjuju svoje kompetencije za rads djecom koja pokazuju emocionalne teškoće i probleme u ponašanju, također bolje procjenjuju i svoju samoefikasnost glede učenja i poučavanja ove djece. Utvrđeno je također da odgojitelji malo znanja stječu tijekom svog inicijalnog obrazovanja, a više kroz samostalan rad i dodatne edukacije. Odgojitelji koji svoje znanje stečeno kroz samostalan rad procjenjuju boljim, osjećaju se i kompetentnijima za rad s djecom koja pokazuju emocionalne teškoće i probleme u ponašanju.

Ključne riječi: predškolsko dijete, emocionalne teškoće i problemi u ponašanju, osjećaj samoefikasnosti nastavnika, kompetentnost odgojitelja 